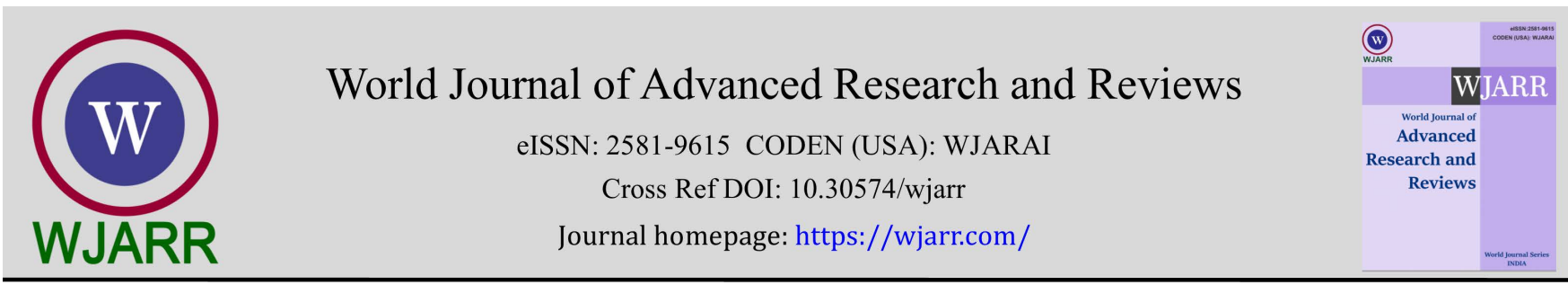

(RESEARCH ARTICLE)

\title{
The microbiology of Kasseri cheese during the maturation
}

\author{
Thomas Bintsis * \\ Hellenic Open University, School of Science \& Technology, Patra, Greece.
}

World Journal of Advanced Research and Reviews, 2021, 10(03), 157-167

Publication history: Received on 25 April 2021; revised on 06 June 2021; accepted on 08 June 2021

Article DOI: https://doi.org/10.30574/wjarr.2021.10.3.0252

\begin{abstract}
The microbiology of Kasseri cheese, a Protected Designation of Origin (PDO) cheese of pasta-filata type was studied in order to identify the dominant species and strains that may contribute to the maturation process. Chemical composition and microbiological quality of Kasseri cheese samples from two different dairies during the maturation was studied at 0, 7, 25, 60 and 90 days of the maturation. Lactic acid bacteria and Enterococcus spp. were found to be the dominant microflora in fresh cheese. P. pentosaceous and P. acidilactici, E. hirae, E. faecium, E. durans and E. gallinarium, together with facultatively heterofermentative lactobacilli were found to be the dominant microflora. Since these strains are dominating the microflora of Kasseri cheese during maturation, the enzymic system need to be further studied in order to select the proper strains for adjunct culture in Kasseri cheese.
\end{abstract}

Keywords: Kasseri cheese; Pasta-filata cheese; Enterococci; Pediococci

\section{Introduction}

Kasseri is a traditional Greek cheese of pasta-filata type. Other cheese categorized as pasta-filata are Provolone, Caciocavallo, Mozzarella and Kashkaval [1]. The PDO status for Kasseri was recognized by the EC in 1996 and amended in 2000 [1]. Traditionally, it was produced in the mountains of Pindos and Olympos. Because milk collection was difficult, shepherds carried out the coagulation of milk and the drainage of cheese curd in the mountains, in order to preserve the milk and diminish its volume, reducing, thus, the cost of transportation [1]. Several drained cheesecurds (called "baskies"), were gathered together and carried for processing to cheese plants. In the meantime, the $\mathrm{pH}$ of the baski dropped (to about pH 5.20) by the activity of the native microflora of the milk. Mature baski was sliced and kneaded in hot water in order to get a pasta-filata texture in nearby factories. According to traditional practice, Kasseri cheese was made from raw milk, because it was considered that kneading eliminated the pathogenic bacteria and controlled the native microflora [2]. The chemical composition of Kasseri cheese is presented in Table 1.

Table 1 Average composition of Kasseri cheese

\begin{tabular}{|l|l|}
\hline chemical composition & percentage \\
\hline Moisture & $35.1-43.0$ \\
\hline Fat in Dry Matter & $32.0-52.3$ \\
\hline Fat & $26.2-29.6$ \\
\hline Salt in Moisture & $2.7-3.3$ \\
\hline $\mathrm{pH}$ & $5.5-5.7$ \\
\hline \multicolumn{2}{|c|}{ Source: Anifantakis (1991) [3] } \\
\hline
\end{tabular}

\footnotetext{
${ }^{*}$ Corresponding author: Thomas Bintsis

Hellenic Open University, School of Science \& Technology, Patra, Greece.

Copyright $(2021$ Author(s) retain the copyright of this article. This article is published under the terms of the Creative Commons Attribution Liscense 4.0.
} 
The technology of Kasseri cheese is described in Figure 1.



Source: Zerfiridis (2001) [4]

Figure 1 Technology of manufacture of Kasseri cheese

\section{Material and methods}

Cheese samples were taken from two dairies (Dairy A and Dairy B) in Thessaly, Central Greece. Two samples from each dairy were taken from two cheese making days at 0 days (fresh cheese) and at 7, 25, 60 and 90 days. Analysis and methods used are shown in Table 2.

In addition, at critical for the maturation points, that is at 0.7 and at the end of the maturation (90 days) sixty (60) colonies were selected from MRS plates with 25-50 colonies. The colonies were purified on MRS agar and were classified and identified based on phenotypical characteristics as described by Bintsis et al. and Psoni et al. [11, 12].

All cultures were stored in MRS Broth + glycerol at $-70^{\circ} \mathrm{C}$.

For the phenotypical characterization of LAB, the scheme shown in Figure 2 was used.

The identification procedure was integrated with sodium dodecyl sulphate poliacrylamide gel electrophoresis SDSPAGE method for the 40 colonies. SDS-PAGE electrophoresis of cell proteins is described by Pot et al. and Piraino et al. $[13,14]$. 
Table 2 Methods used for the analyses of Kasseri cheese

\begin{tabular}{|c|c|}
\hline Parameter & Method \\
\hline \multicolumn{2}{|l|}{ Chemical } \\
\hline Moisture & Drying at $105^{\circ} \mathrm{C}[5]$ \\
\hline Fat & Gerber method [6] \\
\hline Salt & Determination of Chloride Content [7] \\
\hline $\mathrm{pH}$ & Hanna pH meter, Hanna Instruments, Padova, Italy \\
\hline \multicolumn{2}{|l|}{ Microbiological } \\
\hline Total Microbial Count (TMC) & $\mathrm{PCA}, 30^{\circ} \mathrm{C}$ x $48 \mathrm{~h}[8]$ \\
\hline Lactic Acid Bacteria & MRS, $30^{\circ} \mathrm{C}$ x $48 \mathrm{~h}[9]$ \\
\hline Lactic Acid Bacteria & $\mathrm{M} 17,30^{\circ} \mathrm{C}$ x $48 \mathrm{~h}[9]$ \\
\hline Lactic Acid Bacteria & Acetate Agar, $30^{\circ} \mathrm{C}$ x $48 \mathrm{~h}[9]$ \\
\hline Staphylococcus spp. & Baird Parker Agar + Egg Yolk Tellurite Emulsion, $37^{\circ} \mathrm{C} x 48 \mathrm{~h}[9]$ \\
\hline Enterococcus spp. & Citrate Azide Agar, $37^{\circ} \mathrm{C}$ x $72 \mathrm{~h}[10]$ \\
\hline Coliforms & Violet Red Bile Lactose Agar, $30^{\circ} \mathrm{C}$ x $24 \mathrm{~h} \mathrm{[11]}$ \\
\hline Yeasts \& Moulds & Acidified Potato Dextrose Agar, $25^{\circ} \mathrm{C}$ x $72 \mathrm{~h}$ [10]) \\
\hline
\end{tabular}

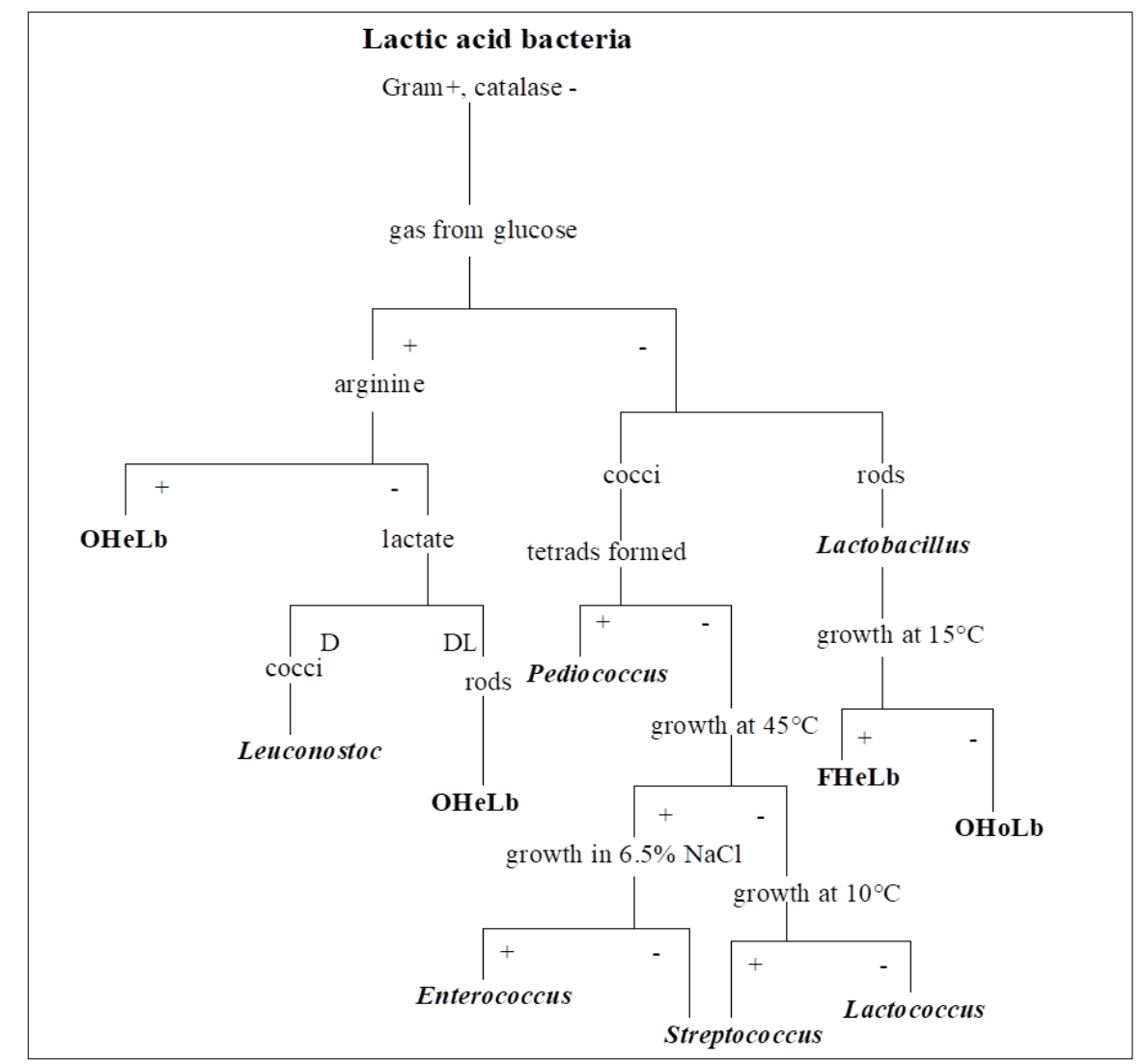

FHeLb: facultative heterofermentative lactobacilli, OHoLb: obligatory homofermentative lactobacilli, OHeLb: obligatory heterofermentative lactobacilli.

Figure 2 Phenotypic characteristics used to classify lactic acid bacteria [Source: Piraino et al. (2006) [15]] 


\section{Results}

The chemical composition of Kasseri cheese produced in the two Dairies studied is shown in Table 3. It can be seen that the $\mathrm{pH}$ of fresh cheese for both samples was close to 5, 3 and at this $\mathrm{pH}$ the procedure of stretching was carried out. Throughout maturation, only small differences were observed for both samples and for the same sample.

The results from the physicochemical analyses agree with the studies for the chemical composition during the maturation of Kasseri cheese [2, 16, 17].

The results for the microbiological analyses throughout the maturation are shown in Table 4 . From Table 4 it can be seen that high numbers for the TMC were found for fresh cheese and for both samples (after the stretching at 70-80을, while higher numbers were found in sample B. Differences in the quality of milk and the hygienic condition in the dairy plant are possible reasons for these differences. Lactic acid bacteria, which were counted on three nutrient agars, were found to be the dominant microflora in fresh cheese, while high numbers of enterococci were also counted. Enterococci were at higher numbers in sample B and in combination with the higher numbers for staphylococci and coliforms it can be said that the hygiene conditions in dairy B need to be improved. However, the numbers of both staphylococci and coliforms are declining during maturation.

At 7 days of ripening, an increase in the numbers of the most important microbial groups is observed. This part of ripening is carried out at room temperature (Figure 1) and is critical for the development of the dominant microflora. These microfloras contribute through their enzymic activities to the biochemical changes taken place during maturation [1]. Lactic acid bacteria were found to be present at high numbers at both cheese samples, and Enterococcus spp. were at high numbers as well.

From 25 days and then, during the maturation, which take place in cold rooms, a gradual reduction in the numbers of main microbial groups is observed for both cheese samples.

Similar results for the development of the microfloras during the maturation of Kasseri cheese [17], Kafalotyri cheese $[18,19]$, Tourkish Kashar cheese [20], Italian Caciocavallo cheese [21] and Spanish Manchego cheese [22] have reported.

It is interesting to note the absence of yeasts and moulds in Kasseri cheese, throughout the maturation. Yeasts constitute an important part of the microfloras in certain cheeses [23], where, with the high enzymic activities contribute to the development of the cheese flavour [24].

Ten colonies from the counts of LAB were selected from each sample from the fresh, at 7 days and at 90 days (a total of 60 colonies). The colonies were purified and phenotypically characterized and classified as shown in Figure 2 . The percentage of the main microbial groups at 0,7 and 90 days are shown in Table 5.

In addition, the method of SDS-PAGE electrophoresis of cell proteins was used as suggested from Pot et al. and Piraino et al. $[13,14]$. The results are presented, in the form of dendrogram (Figure 3). The selected colonies were divided in groups using the statistical program Gel-Compar. Thus, the first group was identified as Enterococcus durans, with a low percentage (50\%). The next group was identified as Enterococcus hirae with a higher percentage (70\%), whereas, with the same percentage was identified the next group as Pediococcus acidilactici. The fourth group was identified as Pediococcus pentosaceous with 75\%, while the grouping percentages for Enterococcus gallinarium and Enterococcus faecium were 40 and $60 \%$ respectively. 
Table 3 Chemical characterization of Kasseri cheese samples from two different dairies during the maturation

\begin{tabular}{|c|c|c|c|c|c|c|c|c|c|c|}
\hline & \multicolumn{2}{|c|}{ Fresh } & \multicolumn{2}{|c|}{7 days } & \multicolumn{2}{|c|}{25 days } & \multicolumn{2}{|c|}{60 days } & \multicolumn{2}{|c|}{90 days } \\
\hline & $\mathbf{A}$ & B & $\mathbf{A}$ & B & $\mathbf{A}$ & B & $\mathbf{A}$ & B & $\mathbf{A}$ & B \\
\hline $\mathrm{pH}$ & $5.32 \pm 0.25$ & $5.31 \pm 0.25$ & $5.33 \pm 0.25$ & $5.32 \pm 0.29$ & $5.43 \pm 0.25$ & $5.41 \pm 0.25$ & $5.48 \pm 0.25$ & $5.42 \pm 0.29$ & $5.47 \pm 0.05$ & $5.43 \pm 0.04$ \\
\hline Moisture & $45.22 \pm 0.63$ & $46.27 \pm 0.52$ & $43.87 \pm 1.31$ & $45.70 \pm 1.45$ & $43.10 \pm 1.63$ & $44.52 \pm 1.73$ & $42.52 \pm 0.81$ & $43.75 \pm 1.00$ & $42.35 \pm 1.35$ & $43.37 \pm 1.31$ \\
\hline Salt & $1.63 \pm 0.34$ & $1.83 \pm 0.21$ & $1.20 \pm 0.13$ & $1.64 \pm 0.58$ & $1.49 \pm 0.48$ & $1.62 \pm 0.43$ & $1.52 \pm 0.42$ & $1.68 \pm 0.38$ & $1.32 \pm 0.26$ & $1.29 \pm 0.39$ \\
\hline Salt in moisture & $3.48 \pm 0.72$ & $3.80 \pm 0.44$ & $2.67 \pm 0.35$ & $3.45 \pm 1.20$ & $3.33 \pm 0.97$ & $3.50 \pm 0.81$ & $3.43 \pm 0.89$ & $3.70 \pm 0.74$ & $3.02 \pm 0.52$ & $2.89 \pm 0.84$ \\
\hline $\begin{array}{l}\text { Fat in Dry } \\
\text { Matter }\end{array}$ & $46.87 \pm 0.61$ & $48.39 \pm 0.42$ & $45.62 \pm 0.73$ & $48.00 \pm 1.63$ & $45.30 \pm 2.17$ & $47.97 \pm 1.20$ & $44.68 \pm 1.45$ & $47.11 \pm 0.59$ & $45.14 \pm 2.31$ & $47.43 \pm 1.33$ \\
\hline
\end{tabular}

A, B: Dairies A and B Figures are mean values in dublicate analyses for two samples from each dairy

Table 4 Microbiological analyses during the maturation of Kasseri cheese from samples from two dairies

\begin{tabular}{|c|c|c|c|c|c|c|c|c|c|c|}
\hline & \multicolumn{2}{|c|}{ Fresh } & \multicolumn{2}{|c|}{ Day 7} & \multicolumn{2}{|c|}{ Day 25} & \multicolumn{2}{|c|}{ Day 60} & \multicolumn{2}{|c|}{ Day 90} \\
\hline & $\mathbf{A}$ & B & $\mathbf{A}$ & B & A & B & $\mathbf{A}$ & B & $\mathbf{A}$ & B \\
\hline TMC & $2.2 \times 10^{7}$ & $2.5 \times 10^{7}$ & $6.8 \times 10^{7}$ & $5.5 \times 10^{7}$ & $1.6 \times 10^{7}$ & $2.7 \times 10^{7}$ & $8.3 \times 10^{6}$ & $1.1 \times 10^{7}$ & $6.9 \times 10^{6}$ & $9.2 \times 10^{6}$ \\
\hline LAB-MRS & $1.4 \times 10^{7}$ & $2.3 \times 10^{7}$ & $2.7 \times 10^{7}$ & $5.8 \times 10^{7}$ & $7.8 \times 10^{6}$ & $2.2 \times 10^{7}$ & $4.3 \times 10^{6}$ & $2.4 \times 10^{7}$ & $4.1 \times 10^{6}$ & $1.3 \times 10^{7}$ \\
\hline LAB-M17 & $1.8 \times 10^{7}$ & $1.9 \times 10^{7}$ & $3.7 \times 10^{7}$ & $4.3 \times 10^{7}$ & $1.5 \times 10^{7}$ & $1.8 \times 10^{7}$ & $5.1 \times 10^{6}$ & $2.1 \times 10^{7}$ & $3.9 \times 10^{6}$ & $1.8 \times 10^{7}$ \\
\hline LAB-Ac. & $1.3 \times 10^{7}$ & $1.1 \times 10^{7}$ & $4.3 \times 10^{7}$ & $3.7 \times 10^{7}$ & $1.8 \times 10^{7}$ & $1.1 \times 10^{7}$ & $3.6 \times 10^{6}$ & $1.2 \times 10^{7}$ & $4.1 \times 10^{6}$ & $8.1 \times 10^{6}$ \\
\hline Staphylococci & $<100$ & $2.5 \times 10^{3}$ & $2 \times 10^{2}$ & $1.4 \times 10^{3}$ & $1.1 \times 10^{2}$ & $6.5 \times 10^{2}$ & $<100$ & $<100$ & $<100$ & $<100$ \\
\hline Enterococci & $4.5 \times 10^{4}$ & $4.2 \times 10^{6}$ & $1.3 \times 10^{5}$ & $2.2 \times 10^{6}$ & $1.5 \times 10^{5}$ & $8.8 \times 10^{5}$ & $6.5 \times 10^{4}$ & $5.5 \times 10^{5}$ & $7.3 \times 10^{4}$ & $3.3 \times 10^{5}$ \\
\hline Coliforms & $<10$ & $2.6 \times 10^{4}$ & $<10$ & $4.4 \times 10^{4}$ & $<10$ & $2.7 \times 10^{3}$ & $<10$ & $2.2 \times 10^{3}$ & $<10$ & $6.5 \times 10^{2}$ \\
\hline Yeasts & $<100$ & $<100$ & $<100$ & $<100$ & $<100$ & $<100$ & $<100$ & $<100$ & $<100$ & $<100$ \\
\hline
\end{tabular}


Table 5 Classification of colonies from MRS as identified using phenotypical characteristics

\begin{tabular}{|c|c|c|c|}
\hline Microbial group & Fresh & Day 7 & Day 90 \\
\hline Pediococcus spp. & $5(25 \%)$ & $7(35 \%)$ & $10(50 \%)$ \\
\hline Enterococcus spp. & $10(50 \%)$ & $9(45 \%)$ & $6(30 \%)$ \\
\hline Lactobacillus spp. & $5(25 \%)$ & $4(20 \%)$ & $4(20 \%)$ \\
\hline  & 20 (100\%) & $20(100 \%)$ & $20(100 \%)$ \\
\hline
\end{tabular}

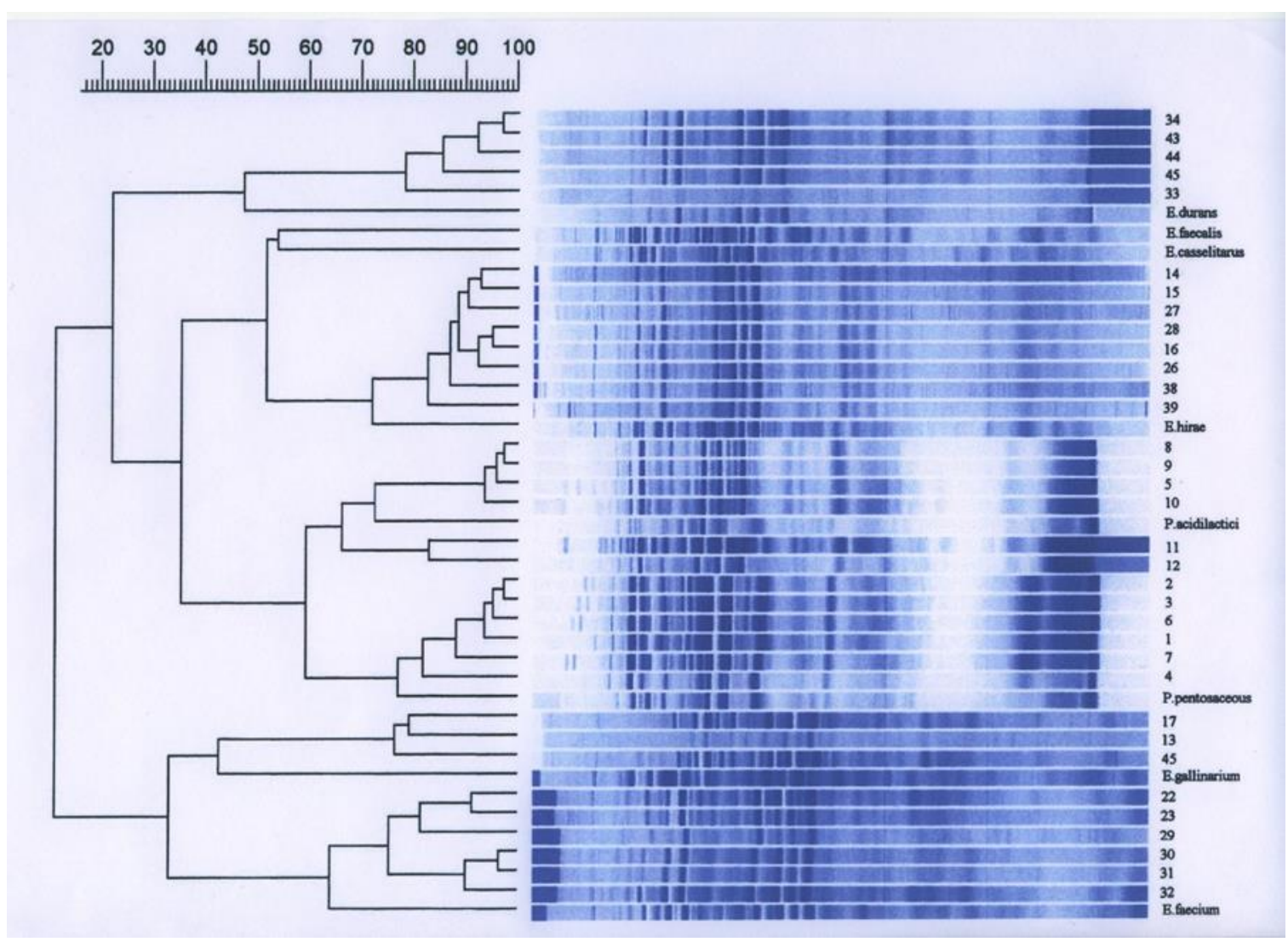

Figure 3 Dendrogram of protein fractions of isolated LAB extracts from Kasseri cheese and reference strains of LAB, using the method of SDS-PAGE electrophoresis

Table 6 Phenotypical characteristics of lactic acid bacteria isolates from Kasseri cheese

\begin{tabular}{|c|c|c|c|c|c|c|c|c|c|c|c|}
\hline & & $\begin{array}{c}\text { Cell } \\
\text { morphology }\end{array}$ & Catalase & 10 & 15 & 45 & $\begin{array}{c}\text { Gas } \\
\text { from } \\
\text { glucose }\end{array}$ & $\mathrm{NH}_{3}$ & $\begin{array}{l}6.5 \% \\
\mathrm{NaCl}\end{array}$ & pH 9.6 & After SDC-PAGE \\
\hline 7A1 & 1 & $\mathrm{C}$ & W & + & ND & - & - & + & - & - & P. pentosaceous \\
\hline 7A2 & 2 & $\mathrm{C}$ & - & + & ND & - & - & + & - & - & P. pentosaceous \\
\hline 7A3 & 3 & $\mathrm{C}$ & W & + & ND & - & - & + & - & - & P. pentosaceous \\
\hline $7 \mathrm{~A} 4$ & 4 & $\mathrm{C}$ & W & + & ND & - & - & + & - & - & P. pentosaceous \\
\hline 7A6 & 5 & $\mathrm{C}$ & - & + & ND & - & - & w & + & + & P. acidilactici \\
\hline 7A10 & 6 & $\mathrm{C}$ & - & + & ND & - & - & + & - & - & P. pentosaceous \\
\hline 1A1E6 & 7 & $\mathrm{C}$ & - & + & ND & - & - & + & - & - & P. pentosaceous \\
\hline
\end{tabular}




\begin{tabular}{|c|c|c|c|c|c|c|c|c|c|c|c|}
\hline 7B3E7 & 8 & $\mathrm{C}$ & - & + & ND & - & - & + & + & + & P. acidilactici \\
\hline 7B4E8 & 9 & $\mathrm{C}$ & - & + & ND & - & - & + & + & + & P. acidilactici \\
\hline 7B7 & 10 & $\mathrm{C}$ & - & + & ND & - & - & + & + & + & P. acidilactici \\
\hline $\mathrm{C} 1$ & 11 & $\mathrm{C}$ & - & + & ND & + & - & + & + & - & P. pentosaceous \\
\hline $\mathrm{C} 7$ & 12 & $\mathrm{C}$ & - & + & ND & + & - & + & + & - & P. pentosaceous \\
\hline 1A2E1 & 13 & $\mathrm{C}$ & - & + & ND & + & - & + & + & - & E. gallinarium \\
\hline 1A9E2 & 14 & $\mathrm{C}$ & - & + & ND & + & - & + & + & + & E. hirae \\
\hline $3 \mathrm{~A} 1 \mathrm{E} 4$ & 15 & $\mathrm{C}$ & - & + & ND & + & - & + & + & + & E. hirae \\
\hline $3 \mathrm{~A} 2 \mathrm{E} 5$ & 16 & $\mathrm{C}$ & - & + & ND & + & - & + & + & + & E. hirae \\
\hline A28E3 & 17 & $\mathrm{C}$ & - & + & ND & + & - & + & + & + & E. gallinarium \\
\hline $7 A 5$ & 22 & $\mathrm{C}$ & - & + & ND & - & - & + & + & + & E. faecium \\
\hline 7A7 & 23 & $\mathrm{C}$ & - & + & ND & - & - & + & + & + & E. faecium \\
\hline 7A8 & 26 & $\mathrm{C}$ & - & + & ND & - & - & + & + & + & E. hirae \\
\hline 7A9 & 27 & $\mathrm{C}$ & - & + & ND & - & - & + & + & + & E. hirae \\
\hline 7B2 & 28 & $\mathrm{C}$ & - & + & ND & - & - & + & + & + & E. hirae \\
\hline 7B5 & 29 & $\mathrm{C}$ & - & + & ND & - & - & + & + & + & E. faecium \\
\hline 7B6 & 30 & $\mathrm{C}$ & - & + & ND & + & - & + & + & + & E. faecium \\
\hline 7B10 & 31 & $\mathrm{C}$ & - & - & ND & - & - & + & + & + & E. faecium \\
\hline $\mathrm{C} 4$ & 32 & $\mathrm{C}$ & - & + & ND & - & - & + & + & - & E. faecium \\
\hline $\mathrm{C} 8$ & 33 & $\mathrm{C}$ & - & + & ND & + & - & + & + & - & E. durans \\
\hline $\mathrm{C} 9$ & 34 & $\mathrm{C}$ & - & + & ND & + & - & - & + & - & E. durans \\
\hline $7 \mathrm{C} 4$ & 43 & $\mathrm{C}$ & - & + & ND & + & - & + & + & - & E. durans \\
\hline $7 \mathrm{C} 5$ & 44 & $\mathrm{C}$ & - & + & ND & + & - & - & + & - & E. durans \\
\hline 7C6 & 45 & $\mathrm{C}$ & - & + & ND & + & - & + & + & - & E. durans \\
\hline $1 \mathrm{~A} 5$ & & $\mathrm{R}$ & - & ND & + & ND & - & ND & ND & ND & Lactobacillus spp. \\
\hline $1 \mathrm{~A} 9$ & & $\mathrm{R}$ & - & ND & + & ND & - & ND & ND & ND & Lactobacillus spp. \\
\hline 7A11 & & $\mathrm{R}$ & - & ND & + & ND & - & ND & ND & ND & Lactobacillus spp. \\
\hline 7B1 & & $\mathrm{R}$ & - & ND & + & ND & - & ND & ND & ND & Lactobacillus spp. \\
\hline 7B9 & & $\mathrm{R}$ & - & ND & + & ND & - & ND & ND & ND & Lactobacillus spp. \\
\hline 1B7 & & $\mathrm{R}$ & - & ND & + & ND & - & ND & ND & ND & Lactobacillus spp. \\
\hline 1B5 & & $\mathrm{R}$ & - & ND & + & ND & - & ND & ND & $\mathrm{ND}$ & Lactobacillus spp. \\
\hline $1 \mathrm{~B} 6$ & & $\mathrm{R}$ & - & ND & + & ND & - & ND & ND & ND & Lactobacillus spp. \\
\hline $1 \mathrm{~B} 10$ & & $\mathrm{R}$ & - & ND & + & ND & - & ND & ND & ND & Lactobacillus spp. \\
\hline
\end{tabular}

\section{Discussion}

Pediococci and enterococci constitute the main microbial groups that dominate the maturation of Kasseri cheese. From the 40 isolates at 0 and 7 days, 31 were found to be cocci 12 Pediococcus spp. -6 P. pentosaceous and 4 P. acidilactici and 19 Enterococcus spp. -6 E. hirae, 6 E. faecium, 5 E. durans and 2 E. gallinarium) and 9 rods (facultatively heterofermentative lactobacilli). 
Tsakalidou et al. [25] identified strains from Kasseri cheese using the method of SDS-PAGE, and found E. faecium, Staphylococcus spp., Lactococcus lactis, Lactobacillus paracasei subsp. tolerans, Lactbacillus delbrueckii, Lactobacillus fermentum, Streptococcus thermophilus and a strain which was first classified as Streptococcus spp. and then as a new species with the name Streptococcus macedonicus.

Pediococci have been reported to be the dominant microflora of certain cheeses. Very early, Dacre [26] reported pediococci to be an important part of Cheddar cheese microflora and constituted the 25\% of the microflora at 6 months. The presence of pediococci has been reported in Cheddar cheese [27, 28, 29, 30, 31], Caciocavallo Pugliese cheese [32] and in mature Kefalotyri [19], and is possible to contribute to the development of the flavor and aroma of each cheese.

Coppola et al. [33] isolated Pediococcus spp. from MRS agar during the maturation of Parmigiano Reggiano; interestingly, pediococci were found at the final stages of the maturation and P. acidilactici was, together with Lactobacilli spp. the dominant genus. In addition, Coppola et al. [34] reported that $P$. acidilactici was part of the dominat microflora of mature Parmigiano Reggiano (at 60, 90, 120 and 150 days) and the same authors concluded that pediococci play an important role at the maturation of such cheeses, contributing to the proteolysis and lipolysis with their enzymic activities. Bouton et al. [35] found pediococci in mature Comté cheese (1, 3 and 5 months but not in the fresh cheese, where enterococci and Streptococcus thermophilus were dominated. Tavaria \& Malcata [36] reported the presence of P. pentosaceous in Serra de Estrela cheese but not in the milk used for the manufacture. P. pentosaceous was found in the dominant microflora of mature Manoura cheese, a hard cheese produced in Sifnos Island in Greece [37].

Pediococcus spp. is one of the most important lactic acid bacteria that are considered as probiotics [38]. Various strains of Pediococcus spp. produce a protein, also known as pediocin, which is considered an effective antimicrobial bacteriocin $[38,39]$. Gandhi et al. [40] studied a peptidoglycan hydrolase, with a characterized antibacterial activity, from $P$. acidilactici, which may be interesting for antagonism with other bacteria in cheese and other fermented food products.

Attri et al. [41] reported that $P$. acidilactici had different proteolytic activities, $\beta$-galactosidase and antioxidant activities, and produced lactic acid; they concluded that $P$. acidilactici is a potential probiotic for humans with all the essential basic probiotic properties. In addition, Gandhi et al. [42] characterized a dipeptidyl peptidase-II from probiotic $P$. acidilactici. Recently, the whole genome of $P$. acidilactici was sequenced and analysed for its evolutionary relationship with other lactic acid bacteria [43]. The genome also encoded different enzyme activities required for utilization of various carbohydrates and encoded genes for probiotics properties.

Enterococci have reported to play a major role in ripening and aroma development in certain cheeses in southern Europe (Portugal, Spain, Italy and Greece) [44]. In Cebreiro, Kefalotyri, Manchego, Picante da Beira Baixa and Teleme cheeses, enterococci are the predominant microorganisms in the fully ripened cheese [44]. The beneficial role of enterococci in cheese-making has attributed to the lipolysis of milk by esterases [45] and enterococcal strains have been included in certain starter cultures.

However, some Enterococcus spp., especially E. faecium and E. faecalis may be considered as opportunistic pathogens, and, in case they carry antibiotic resistance genes and possible virulence factors, they would constitute a definite health risk [44].

It is interesting to note the absence of Lactococcus spp. from Kasseri cheese and this can be possibly explained by their thermosensitivity, [46] as they cannot survive the kneading stage. Similarly, Aran [20] reported the absence of lactococci from the Kashar cheese, a Turkish cheese from the category of pasta-filata. On the other hand, enterococci, which are thermoresistant microorganisms, were found in the dominant microflora of Kashar cheese [20]. E. faecium and E. durans were the dominant species. The presence of high numbers of Enterococcus spp. has reported for cheese such as Manchego [22], Mozzarella [47, 48] Serra [49], Kefalotyri [19], Feta and Telemes [50], Cebreiro [51] and Compté cheese [35].

\section{Conclusion}

The quality and the contribution of the microbiology during the maturation of Kasseri cheese were studied, together with the changes throughout. The main microbial groups were identified. It was found that the dominated strains belong to the genera of Pediococcus, Enterococcus and Lactobacillus. More specifically, P. pentosaceous and P. acidilactici, E. hirae, E. faecium, E. durans and E. gallinarium, together with facultatively heterofermentative lactobacilli. The biotechnological properties of these strains are needed to be further studies in order to select adjunct cultures for the standardized production of Kasseri and other pasta-filata cheese. 


\section{Compliance with ethical standards}

\section{Acknowledgments}

The provision of cheese samples from the two dairies from Trikala, Greece is acknowledged.

\section{Disclosure of conflict of interest}

The author hereby declares that there is no conflict of interest that could arise.

\section{References}

[1] Licitra G, Radulovic Z, Miocinovic J, Uzunsoy, I, Ozer B, Bintsis T, Alichanidis E, Herian K, Jelen P. Pasta-Filata Cheeses, In: Papademas P. and Bintsis T. (Eds). Global Cheesemaking Technology: Cheese Quality and Characteristics, John Wiley \& Sons Ltd., Chichester, UK. 2018; 368-391.

[2] Moatsou G, Kandarakis I, Moschopoulou E, Anifantakis E, Alichanidis E. Effect of technological parameters on the characteristics of kasseri cheese made from raw or pasteurized ewes' milk. International Journal of Dairy Technology. 2001; 54 (2): 69-77.

[3] Anifantakis EM. Greek cheeses. National Dairy Committee, Athens. 1991.

[4] Zerfiridis GK. Technology of Milk Products I. Cheesemaking. 2th Edition, Giahoudi publishers, Thessaloniki, Greece. 2001.

[5] IDF. International Standards for the Determination of Total Solids in Cheese, Standard 4A, International Dairy Federation, Brussels, Belgium. 1982.

[6] BSI. Gerber Method for the Determination of Fat in Milk and Milk Products. BS 696 part 2, British Standards Institution, London, UK. 1989.

[7] BSI. Chemical Analysis of Cheese: Determination of Chloride Content. BS 770 part 4, British Standards Institution, London, UK. 1989.

[8] IDF. Milk and Milk Products: Enumeration of Microorganisms, Colony Count Technique at $30^{\circ} \mathrm{C}$, Standard $100 \mathrm{~B}$, International Dairy Federation, Brussels, Belgium. 1991.

[9] Harrigan W F. Laboratory Methods in Food Microbiology. $3^{\text {rd }}$ Edition. Academic Press Limited, London. 1998.

[10] Marshall RT. Standard Methods for the Examination of Dairy Products. $16^{\text {th }}$ Edition, American Public Health Association, Washington. 1992.

[11] IDF. Enumeration of Coliforms at $30^{\circ} \mathrm{C}$, Standard 73A, International Dairy Federation, Brussels, Belgium. 1985.

[12] Bintsis T, Litopoulou-Tzanetaki E, Davies R, Robinson RK. Microbiology of brines used to mature feta cheese. International Journal of Dairy Technology. 2000; 53(3): 106-112.

[13] Psoni L, Tzanetakis N, Litopoulou-Tzanetaki E. Microbiological characteristics of Batzos, a traditional Greek cheese from goat's milk. Food Microbiology. 2003; 20: 575-582.

[14] Pot B, Vandamme P, Kersters K. Analysis of electrophoretic, whole organism protein fingerprints. In: Goodfellow M and O'Donnel A G (Eds), Chemical Methods in Procaryotic Systematics. 1994; 493-521.

[15] Piraino P, Ricciardi A, Salzano G, Zotta T, Parente E. Use of unsupervised and supervised artificial neural networks for the identification of lactic acid bacteria on the basis of SDS-PAGE patterns of whole cell proteins. Journal of Microbiological Methods. 2006; 66: 336-346.

[16] Sharpe ME. Lactic acid bacteria in the dairy industry. Journal of the Society of Dairy Technology. 1979; 32(1): 918.

[17] Kaminarides SE, Siaravas V, Potetsianaki I. Comparison of 2 methods of making kneaded plastic cheese from ewe's milk. Lait. 1995; 75: 181-189.

[18] Kaminarides S, Parsschopoulos N, Beri I. Combined effects of concentrated thermophilic and mesophilic cultures and conditions of curd acidifications on the manufacture and quality of kasseri cheese. International Journal of Dairy Technology. 1999; 52(1): 11-19. 
[19] Anifantakis EM, Kaminarides SE. Effect of various starters on the quality of Kefalotyri cheese. LeLait. 1987; 67: 527-536.

[20] Litopoulou-Tzanetaki E. Changes in Numbers and Kinds of Lactic Acid Bacteria during Ripening of Kefalotyri Cheese. Journal of Food Science. 1990; 55(1): 111-113.

[21] Aran N. A microbiological study of Kashar cheese. Milchwissenschaft. 1998; 53(10): 565-567.

[22] Coppola R, Succi M, Sorrentino E, Iorizzo M, Grazia L. Survey of lactic acid bacteria during the ripening of Caciocavallo cheese produced in Molise. Lait. 2003; 83: 211-222.

[23] Ordonez J A, Barneto R, Ramos M. Studies on Manchego cheese ripened in olive oil. Milchwissenschaft. 1978; 33: 609-613.

[24] Bintsis T, Papademas P. Microbiological quality of white-brined cheeses: a review. International Journal of Dairy Technology. 2002; 55(3): 113-120.

[25] Bintsis T, Vafopoulou-Mastrojiannaki A, Litopoulou-Tzanetaki E, Robinson RK. Protease, peptidase and esterase activities by lactobacilli and yeast isolates from Feta cheese brine. Journal of Applied Microbiology. 2003; 95: 6877.

[26] Tsakalidou E, Zoidou E, Pot BDF. Identification of streptococci from Greek Kasseri cheese and description of Streptococcus macedonicus sp. nov. International Journal of Systematic Bacteriology. 1998; 48 (2): $519-527$.

[27] Dacre JC. A note on the pediococci in New Zealand Cheddar cheese. Journal of Dairy Research. 1958; 25: $414-416$.

[28] Thomas TD, McKay LL, Morris HA. Lactate metabolism by pediococci isolated from Cheddar. Applied and Environmental Microbiology. 1985; 4: 908-913.

[29] Litopoulou-Tzanetaki E, Graham DC, Beyatli Y. Detection of pediococci and other non-starter organisms in American Cheddar cheese. Journal of Dairy Science. 1989; 72: 854-858.

[30] Bhowmik T, Marth EH. Role of Micrococcus and Pediococcus species in cheese ripening: A review. Journal of Dairy Science. 1990; 73: 859-866.

[31] Bhowmilk T, Marth EH. Peptide-hydrolysing enzymes of Pediococcus species. Microbios. 1990; 62: $197-211$.

[32] Bhowmik T, Riestere R, Van Boekel MAJS, Marth EH. Characteristics of low-fat Cheddar cheese made with added Micrococcus or Pediococcus species. Milchwissebschaft. 1990; 45(4): 230-235.

[33] Gobbetti M, Morea M, Baruzzi F, Corbo MR, Matarante A, Considine T, Di Cagno R, Guinee T, Fox PF. Microbiological, compositional, biochemical and textural characterization of Caciocavallo Pugliese cheese during ripening. International Dairy Journal. 2002; 12: 511-523.

[34] Coppola R, Nanni M, Iorizzo M, Sorrentino A, Sorrentino E, Grazia L. Survey of lactic acid bacteria isolated during the advanced stages of the ripening of Parmigiano Reggiano. Journal of Dairy Research. 1997; 64: 305-310.

[35] Coppola R, Nanni M, Iorizzo M, Sorrentino A, Sorrentino E, Grazia L. Microbiological characteristics of Parmigiano Reggiano cheese during the cheesemaking and the first months of the ripening. Lait. 2000; 80: 479-490.

[36] Bouton Y, Guyot P, Grappin P. Preliminary characterization of microflora of Comté cheese. Journal of Applied Microbiology. 1998; 85: 123-131.

[37] Tavaria FK, Malcata F. Microbiological characterization of Serra da Estrela cheese throughout its AOP region. Journal of Food Protection. 1998; 61(5): 601-607.

[38] Gerasi E, Litopoulou-Tzanetaki E, Tzanetakis N. Microbiological study of Manura, a hard cheese made from raw ovine milk in the Greek island Sifnos. International Journal of Dairy Technology. 2003; 56 (2): 117-122.

[39] Porto MC, Kuniyoshi TM, Azevedo PO, Vitolo M, Oliveira RP. Pediococcus spp.: an important genus of lactic acid bacteria and pediocin producers. Biotechnology Advances. 2017; 35(3): 361-374.

[40] Papagianni M, Anastasiadou S. Pediocins: the bacteriocins of Pediococci. Sources, production, properties and applications. Microbial Cell Factories. 2009; 8: 3.

[41] Gandhi D, Chanalia P, Bansal P, Dhanda S. Peptidoglycan Hydrolases of Probiotic Pediococcus acidilactici NCDC 252: Isolation, Physicochemical and In Silico Characterization International Journal of Peptide Research and Therapeutics. 2020. 
[42] Attri P, Jodha D, Gandhi D, Chanalia P, Dhanda S. In vitro evaluation of Pediococcus acidilactici NCDC 252 for its probiotic attributes. International Journal of Dairy Technology. 2015; 67: 1-10.

[43] Gandhi D, Chanalia P, Attri P, Dhanda S. Dipeptidyl peptidase-II from probiotic Pediococcus acidilactici: Purification and functional characterization, International Journal of Biological Macromolecules. 2016.

[44] Bansal P, Kumar R, Singh J, Dhanda S. Next generation sequencing, biochemical characterization, metabolic pathway analysis of novel probiotic Pediococcus acidilactici NCDC 252 and it's evolutionary relationship with other lactic acid bacteria Molecular Biology Reports. 2019.

[45] Franza CMAP, Holzapfelb WH, Stilesa ME. Enterococci at the crossroads of food safety? International Journal of Food Microbiology. 1999; 47: 1-24.

[46] Tsakalidou E, Manolopoulou E, Tsilibari V, Georgalaki M, Kalantzopoulos G. Esterolytic activities of Enterococcus durans and Enterococcus faecium strains isolated from Greek cheese. Netherlands Milk and Dairy Journal. 1993; 47: 145-150.

[47] Grappin R, Beuvier E. Possible implications of milk pasteurization on the manufacture and sensory quality of ripened cheese. International Dairy Journal. 1997; 7: 751-761.

[48] Coppola TM, Parente JE, Dumontet S, La Peccerella A. The microflora of natural whey cultures utilized as starters in the manufacture of Mozzarella cheese from water buffalo milk. Lait. 1988; 68: 295-310.

[49] Macedo CA, Malcata FX, Hogg TA. Microbiological profile in Serra ewe's cheese during ripening. Journal of Applied Bacteriology. 1995; 79: 1-11.

[50] Tzanetakis N, Litopoulou-Tzanetaki E. Changes in numbers and kinds of lactic acid bacteria in Feta and Teleme, two Greek cheeses from ewe's milk. Journal of Dairy Science. 1992; 75 (6): 1389-1393.

[51] Centeno JA, Menéndez S, Rodriguez-Otero JL. Main microbial flora present as natural starters in Cebreiro raw cow's milk cheese (Northwest Spain). International Journal of Food Microbiology. 1996; 33: 307-313. 